\title{
Experimental study on optimization of multiple substrates anaerobic co-digestion
}

\author{
Xuemei Wang ${ }^{1, a}$, Zifu li ${ }^{1, b,{ }^{*}}$, Ruiling Gao ${ }^{1, c}$, Fubin Yin ${ }^{1 d}$, Dongling Wang ${ }^{1 e}$ \\ ${ }^{1}$ School of Civil and Environmental Engineering, Beijing Key Laboratory of Resource-oriented \\ Treatment of Industrial Pollutants, University of Science and Technology Beijing , Beijing and \\ 100083, China \\ awangxuemei0000@126.com, ${ }^{b}$ zifulee@aliyun.com, c gaoruiling1988@126.com, ${ }^{\text {d }}$ carft_257@163.c \\ om, ${ }^{\mathrm{e}} 379514343 @ q q . c o m$
}

Keywords: Cow Manure; Corn Straw; Vegetable Residues; Anaerobic Co-Digestion; Biogas Production Enhancement.

\begin{abstract}
Co-digestion is becoming an important method to increase specific biogas production. Co-digestion of cow manure with corn straw was investigated and optimized in this study, and the influence of vegetable residues additive on co-digestion was explored preliminarily. The research was divided into two parts, i.e., the co-digestion of cow manure and corn straw was carried out in part $\mathrm{A}$, and the co-digestion of cow manure, corn straw and vegetable residues was carried out in Part B. The experimental design with duplicates was adopted to examine the improvement of batch digestion in terms of biogas production volume, $\mathrm{CH}_{4}$ content in the biogas, contents variation of cellulose and lignin. All the digesters were run simultaneously under controlled temperature at $37 \pm 0.1{ }^{\circ} \mathrm{C}$. The results showed that the corn straw addition significantly increased biogas production, among which the substrate, with 1/7 of TS ratio of corn straw to cow manure, performed the best with a accumulative biogas volume of $350.01 \mathrm{ml} / \mathrm{g} \bullet \mathrm{VS}$, increasing by $30.19 \%$ compared to the cow manure digestion alone. However, adding 1\% (TS) vegetable residues to the mixture of corn straw and caw manure didn't bring about a significant change in biogas production, the addition of vegetable residues greater than $5 \%$ (TS) caused the acidification problem. The results show that it was efficient to improve the biogas productivity by co-digesting corn straw and cow manure, but the acidification problem should be avoided when adding vegetable residues.
\end{abstract}

\section{Introduction}

Due to energy crisis and environmental problems, anaerobic digestion is one of the most promising ways to produce renewable energy from energy crops, manures and other organic materials. Agricultural wastes like manure and straw are commonly available and are used feedstock in anaerobic digestion[1]. Manures have a low $\mathrm{C} / \mathrm{N}$ and straws have a high $\mathrm{C} / \mathrm{N}$, digesting alone usually results in a low biogas yield, while co-digestion of straws and manures has the synergetic effects. Manures provide good buffering capacity and a wide range of nutrients, while the addition of straws increases the energy yield of the process[2, 3]. Weiland proposed that co-fermentation and optimal mixture of different substrates would have a great potential for high efficient biogas production. In Germany, it is reported that almost half of all the biogas plants are using agricultural residues and animal manure for co-fermentation biogas production[4].

In this study, the typical crop residues and livestock manures such as corn straw and cow manure in the suburban of Beijing were selected to investigate the biogas yield of anaerobic co-digestion under mesophilic anaerobic fermentation condition in terms of different mixture ratios. Based on the analysis of the biogas production, methane content, $\mathrm{pH}$, and the change of cellulose and lignin, etc., the ratio of straw and manure was optimized. Besides, as vegetables have the characteristics of high moisture, organic content (volatile solid) and easy biodegradation, especially being rich in micronutrients, vegetable residues as additive to the co-digestion of corn straw and cow manure was investigated [5]. 


\section{Material and methods}

\subsection{Origin of materials}

The substrate of this research are corn straw, cow manure and vegetable residues. The fresh cow manure was obtained from the Sanyuan Treasure Island dairy farm in Beijing. Inoculum was obtained from a mesophilic anaerobic digester which was processing dairy manure from the same dairy farm. After harvesting the corn straw in the farmland of Daxing region in Beijing, the material was cutting into small pieces with a particle size of approximately $5 \mathrm{~mm}$. The vegetable residues, collected from the fruit and vegetable market in our university, were also cut into small pieces with a particle size of approximately 5mm. Table 1 shows the chemical and physical characteristics of the materials.

Table 1 Chemical and physical characteristics of raw materials

\begin{tabular}{cccccccccc}
\hline Raw materials & $\mathrm{pH}$ & $\mathrm{TS}(\%)$ & $\mathrm{VS}(\%)$ & $\mathrm{oTM}(\%)$ & $\mathrm{H}$ & $\mathrm{S}$ & $\mathrm{C}$ & $\mathrm{N}$ & $\mathrm{C} / \mathrm{N}$ \\
\hline corn straw & - & 92.15 & 90.56 & 83.45 & 6.32 & 0.33 & 42.98 & 0.82 & 52.41 \\
cow manure & 7.33 & 23.41 & 38.79 & 9.08 & 4.99 & 0.81 & 33.66 & 2.01 & 16.75 \\
vegetable residues & 6.50 & 5.66 & 83.60 & 4.68 & - & - & - & - & 13.46 \\
\hline
\end{tabular}

\subsection{Experimental set-up}

The experiment was carried out in the Automatic Methane Potential Test System imported from Sweden. The reactors consist of 15 glass bottles, each with a total volume of $500 \mathrm{ml}$, stirred continuously at $85 \mathrm{rpm}$, and controlled at $37 \pm 1{ }^{\circ} \mathrm{C}$. The real-time data logging of accumulated bio-methane volume and flow rate were available by Automatic Methane Potential Test System, of which the measuring resolution is $10 \mathrm{ml}[6]$. Figure. 1 shows the system.

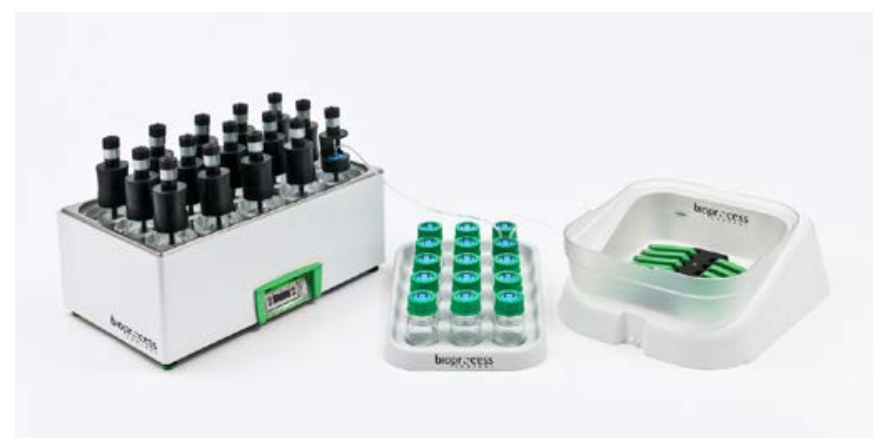

Fig. 1 Automatic Methane Potential Test System

\subsection{Experimental design}

Two parts (part A and part B) of experiments performed sequentially. First, in part A, the co-digestion of cow manure and corn straw was carried out, grouping by the ratios of corn straw and caw manure with $1 / 4,1 / 5,1 / 6,1 / 7,1 / 8,1 / 9,1 / 10,1 / 20$ based on TS respectively. And all the mix ratio of substrates was calculated on TS. Besides, a control test with cow manure digestion were operated. Based on the experimental results of part A, the best mixture ratio of corn straw and caw manure was applied in part B. In part B, the vegetable residues of $1 \%, 5 \%, 10 \%$ (calculated on dry weight of cow manure) as additive were put into the co-digestion reactors respectively. The ratio of $\mathrm{TS}_{\text {inoculum }}$ to TS/substrate was 0.5[7]. Table 2 shows the composition and added amounts of the experiments. 
Table 2 Composition and added amounts in the reactors [g]

\begin{tabular}{cccccc}
\hline \multicolumn{2}{c}{ No. } & corn straw & cow manure & vegetable residues & ratio $\left(\mathrm{TS}_{\text {corn straw }} / \mathrm{TS}_{\text {caw manure }}\right)$ \\
\hline & 1 & 0 & 0 & 0 & - \\
& 2 & 0 & 128.21 & 0 & - \\
& 3 & 8.14 & 128.21 & 0 & $1 / 4$ \\
& 4 & 6.51 & 128.21 & 0 & $1 / 5$ \\
$\mathrm{~A}$ & 5 & 5.43 & 128.21 & 0 & $1 / 6$ \\
& 6 & 4.65 & 128.21 & 0 & $1 / 7$ \\
& 7 & 4.07 & 128.21 & 0 & $1 / 8$ \\
& 8 & 3.62 & 128.21 & 0 & $1 / 9$ \\
& 9 & 3.26 & 128.21 & 0 & $1 / 10$ \\
& 10 & 1.63 & 128.21 & 0 & $1 / 20$ \\
\hline & 1 & 4.65 & 128.21 & 5.30 & $1 / 7 / 0.07$ \\
B & 2 & 4.65 & 128.21 & 26.50 & $1 / 7 / 0.35$ \\
& 3 & 4.65 & 128.21 & 53.00 & $1 / 7 / 0.7$ \\
\hline
\end{tabular}

\subsection{Method}

During the anaerobic digestion, the biogas production, methane content, TS, VS, $\mathrm{pH}, \mathrm{C}, \mathrm{H}, \mathrm{S}, \mathrm{N}$, cellulose and lignin were measured. The biogas production was obtained in real-time by the Automatic Methane Potential Test System. The methane content of biogas was measured using the Geotech-Biogas Check. The TS and VS were determined according to China standard methods under the temperature of $105{ }^{\circ} \mathrm{C}$ and $550{ }^{\circ} \mathrm{C}$ respectively. The $\mathrm{pH}$ was measured with a Mettler Toledo $\mathrm{pH}$-meter. The basic elements of $\mathrm{C}, \mathrm{H}, \mathrm{S}, \mathrm{N}$ were analyzed in the Elemental Analyzer - 3000. The content of cellulose and lignin were measured by the Raw Fiber Determination Equipment-SLQ-201.

\section{Results and discussion}

\section{1 part $\mathrm{A}$}

\subsubsection{Biogas production in part $A$}

As Figure. 2 and Figure. 3 show, all the biogas productions reached the peaks with the $\mathrm{CO}_{2}$ content of over $80 \%$ in all the 10 sets from the $1^{\text {th }}$ day to the $3^{\text {th }}$ day. The second peaks happened differently, but still ranging from the $4^{\text {th }}$ day to the $8^{\text {th }}$ day. With addition of less corn straws, the sets of A7-A10 got the earlier second biogas production peaks, then tending to be stable. Furthermore, from the $3^{\text {th }}$ day, the methane contents of all the 10 sets except A1 exceeded $60 \%$. As the control test, the biogas production in A1 with just inoculum was relatively lower. The highest daily biogas production turned up in $\mathrm{A} 8,533.1 \mathrm{ml} / \mathrm{day}$, showed on the $4^{\text {th }}$ day, while in the biogas production-optimal set (A6), the highest daily biogas production was $434.8 \mathrm{ml} /$ day, also happened on the $4^{\text {th }}$ day. However the peak daily biogas production in A6 was a little lower than that in A8, but the biogas cumulative yield in A6 was the highest with the more stable operation system. In the set of A6, another small peak turned up on the $15^{\text {th }}$ day, with a daily biogas production of $310.5 \mathrm{ml} /$ day, possibly on account of that the methanogens were in the ascendant in the later stage, while the acidogens were dominant in the initial stage. It turned out that the ratio of corn straw and caw manure in A6 (1/7) was the optimal with the best biogas production performance, in which there was the synthetic effect between cow manure and corn straw so as to promote each other's biogas production[1]. 


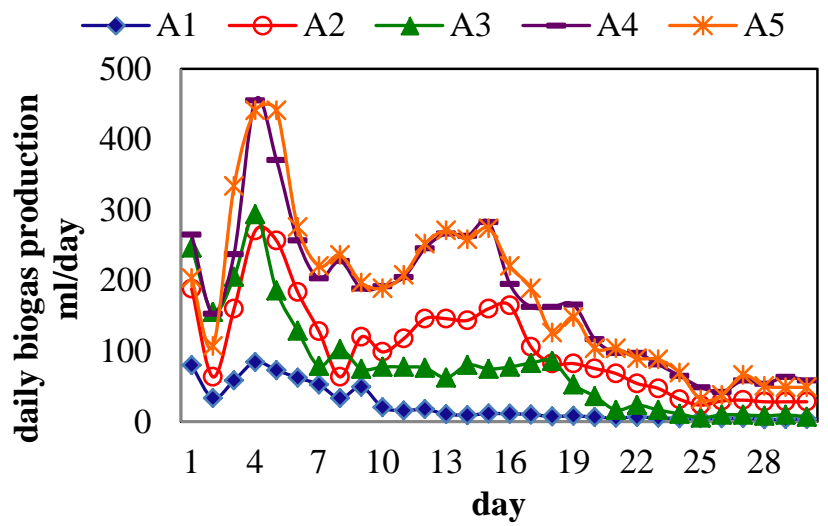

Fig. 2 Daily biogas productions in A1-A5

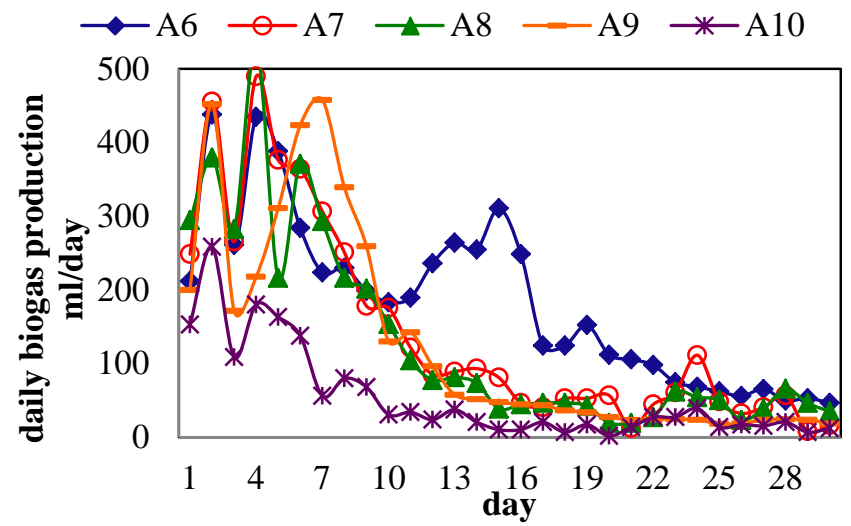

Fig. 3 Daily biogas productions in A6-A10

As Figure. 4 shows, after the 30 days-test period of anaerobic digestion, the total biogas productions in A1-A10 were $704.01 \mathrm{ml}, 3128.62 \mathrm{ml}, 2374.56 \mathrm{ml}, 5284.48 \mathrm{ml}, 5331.98 \mathrm{ml}, 5546.92$ $\mathrm{ml}, \quad 4259.92 \mathrm{ml}, 3935.72 \mathrm{ml}, 3763.82 \mathrm{ml}, 1608.95 \mathrm{ml}$ respectively, in which the highest biogas production with $5546.92 \mathrm{ml}$ turned up in A6, equating to $350.01 \mathrm{ml} / \mathrm{g} \bullet \mathrm{VS}$, exceeding $30.19 \%$ compared to the set of A2 without corn straw.

However, not all the tests with additions of corn straws performed promoting roles in A3-A10. In A3 and A10 corn straw addition inhibited the biogas production which were $53.54 \%$ and $54.36 \%$ respectively lower than $\mathrm{A} 2$ (without corn straw). As Table 3 shows, $\mathrm{C} / \mathrm{N}$ in $\mathrm{A} 3$ was 23.88 which was in a suitable range theoretically, but the additive amount of corn straw might be too much for a stable anaerobic digestion system initially, leading to acidification. In A10, the biogas production fell off sharply with the ratio of $1 / 20$. It might be due to some undesirable inhibitors that needs further research[8]. Finally, the biogas productions in A7, A8 and A9 were similar to A2 and corn straw had little impact on biogas production.

The ratios of corn straw and cow manure in A3 and A10 were 1/4 and 1/10. For good anaerobic co-digestion condition, it proved that the ratio should be in a reasonable range of $1 / 5$ to $1 / 10$ as the result of this research.

Table $3 \mathrm{C} / \mathrm{N}$ in part $\mathrm{A}[\%]$

\begin{tabular}{ccccccccccc}
\hline No. & A1 & A2 & A3 & A4 & A5 & A6 & A7 & A8 & A9 & A10 \\
\hline C/N & - & 16.75 & 23.88 & 22.69 & 21.85 & 21.21 & 20.71 & 20.32 & 19.99 & 18.45 \\
\hline
\end{tabular}
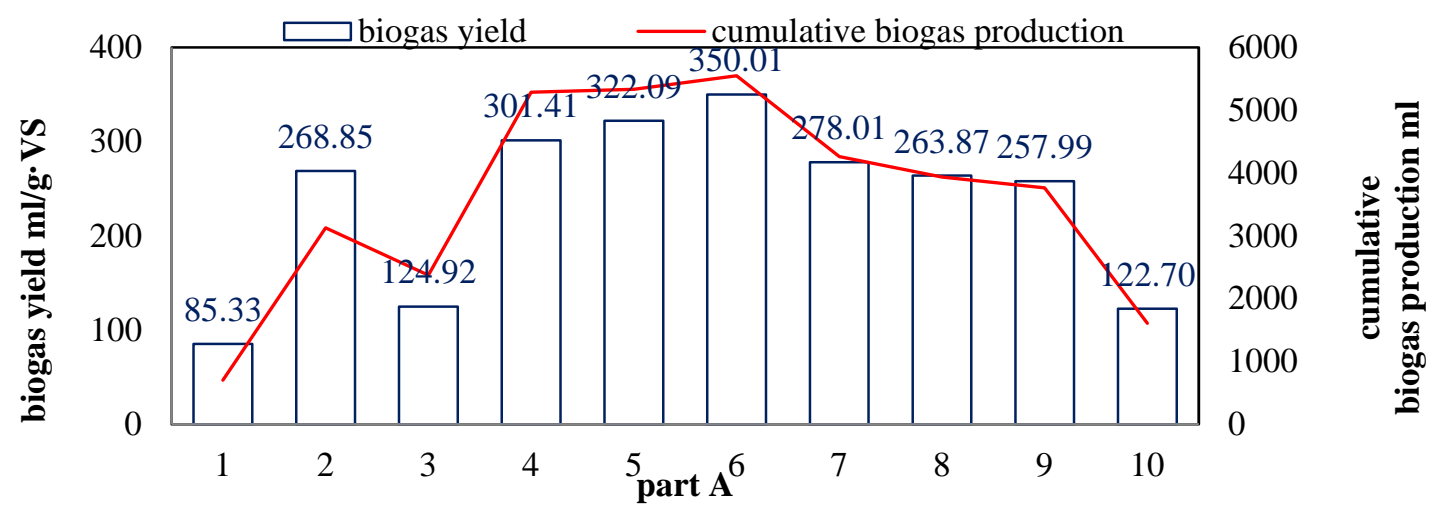

Fig. 4 Specific and cumulative biogas productions in different sets

\subsubsection{The change of cellulose and lignin contents in part $A$}

As Figure. 5 and Figure. 6 show, before and after the anaerobic digestion, cellulose content (the percentage of cellulose in per gram dry straw) and lignin content (the percentage of lignin in per gram dry straw) did not show significant changes. During the anaerobic process, the lignin was stripped away from the cellulose, promoting the degradation of cellulose. The dissolved cellulose were metabolized by microbes, but that amount was very little, leading to the little change of cellulose and 
lignin contents[9]. As the substrate of anaerobic digestion, the corn straws might need to be pretreated using some pretreatment processes such as adding enzyme and fungicide to improve the utilization rate of cellulose[10].

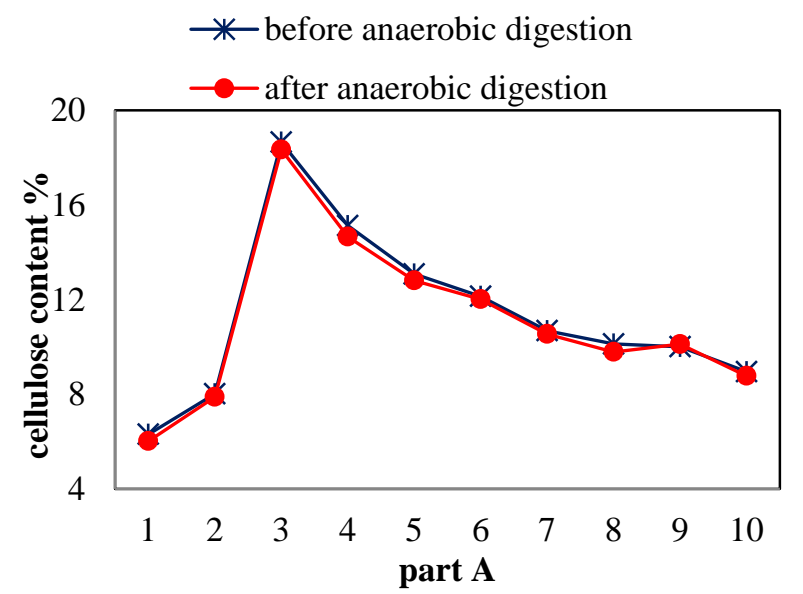

Fig. 5 Change of cellulose content in part A

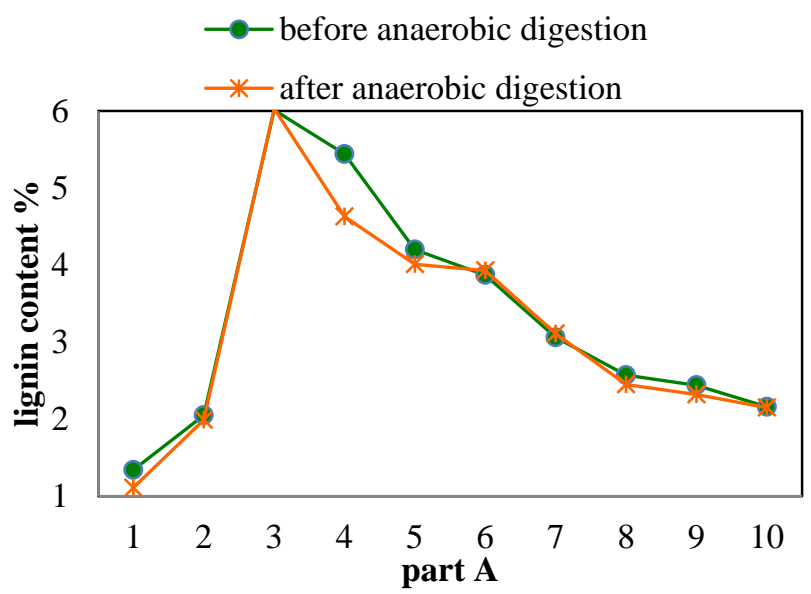

Fig. 6 Change of lignin content in part A

\section{1 part $A$}

On the basis of the results of part $A$, the optimal ratio of corn straw and cow manure was $1 / 7$ in part B. For exploring the effect of vegetable residues on anaerobic co-digestion (if vegetable residues could be used as microelement or not), different contents of vegetable residues were added as the third kind of substrates in the co-digestion, with 1\%, 5\%, 10\% respectively. Figure. 7 showsthat in B1 with a additive amount of $1 \%$, the total biogas production in 30 days was $5228.99 \mathrm{ml}$, equating to $324.81 \mathrm{ml} / \mathrm{g} \bullet \mathrm{VS}$, 8\% lower than that in A7. It turned out that only $1 \%$ vegetable residues didn't make significant sense. Focusing the $\mathrm{pH}$ in Figure. 8, $\mathrm{pH}$ in B1 didn't change clearly before and after anaerobic digestion, showing a relatively stable system. However, in B2 and B3, the problem of acidification emerged from the $3^{\text {th }}$ day, as the $\mathrm{pH}$ declined to 6 and below. Abundant volatile fatty acids accumulated in the initial stage as hydrolysis reaction proceeded quickly because of vegetable residues addition and acidogens prevailed over the other microbes. The volatile fatty acids could not be consumed quickly, leading to the acidification and system crash[11]. It turned out that co-digestion with vegetable residues need nutrient balance to keep the system stable[12].

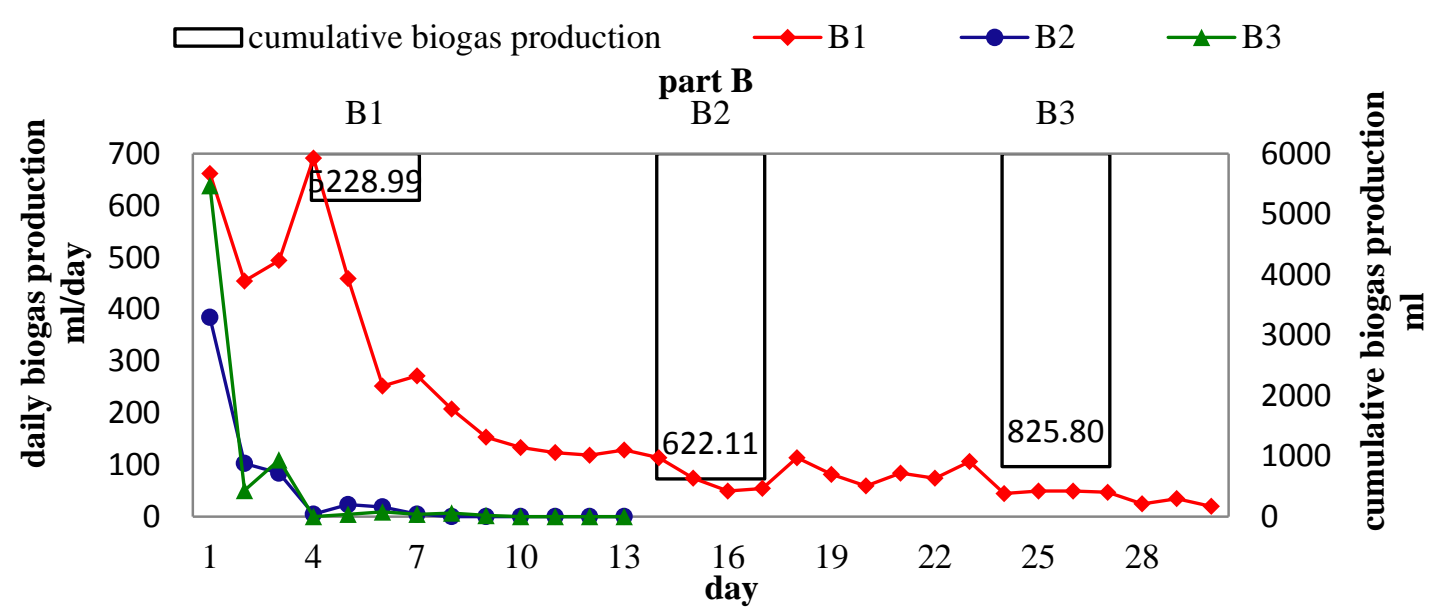

Fig. 7 Change of daily biogas production in part B 


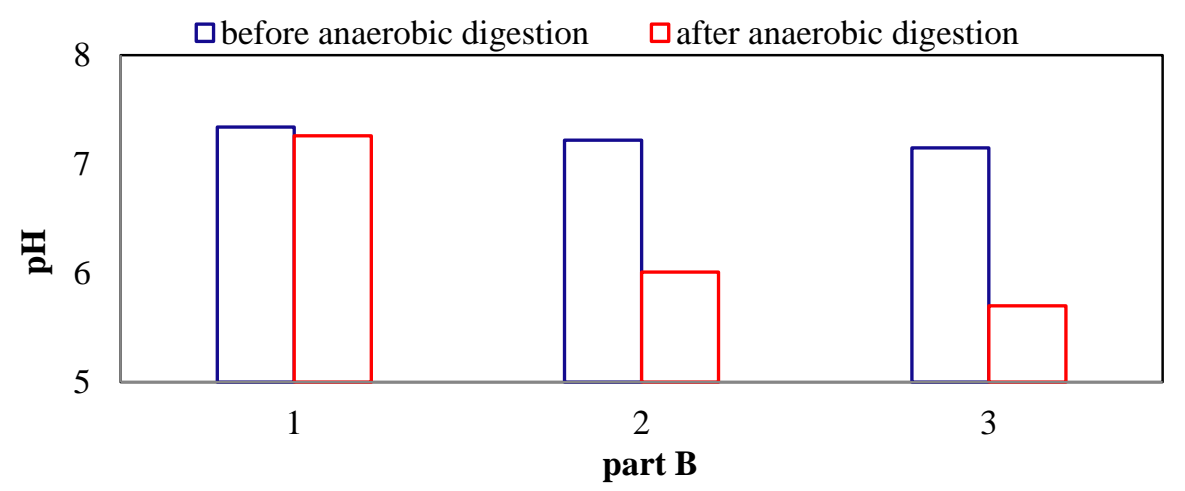

Fig. 8 Change of $\mathrm{pH}$ in part $\mathrm{B}$

\section{Conclusions}

In consideration of the nutrient requirements of anaerobic microbes, co-digesting of corn straw and cow manure in a reasonable ratio promoted the biogas production and kept the system stable. And the stability of continuous operating co-digestion system should be explored further[13].

The highest total biogas production (5546.92 ml) turned up in A6 (1/7), equating to 350.01 $\mathrm{ml} / \mathrm{g} \bullet \mathrm{VS}$, exceeding $30.19 \%$ compared to A2 without corn straw addition. As the cellulose and lignin contents were relatively high in corn straw and cow manure, the co-digestion could not be helpful to degrade the cellulose and lignin. Pretreatment like adding enzyme and fungicide may be required.

Adding 1\% vegetable residues did not promote the biogas production compared to A6. But the addition of vegetable residues greater than $5 \%$ could cause the acidification problem, which should be avoided by adjusting nutrient composition in the digester.

\section{Acknowledgements}

This study was supported by grants from International Scientific and Technological Cooperation and Exchange Projects (2013DFG92620) and Beijing Science and Technology Program (D141100001214003). The authors wish to thank the Beijing Sanyi Green Energy Development Co., Ltd and the SanyuanTreasure Island dairy farm.

\section{References}

[1] Sepp I M, Pyykk nen V, V is nen A, et al. Biomethane production from maize and liquid cow manure $i \S C$ Effect of share of maize, post-methanation potential and digestate characteristics[J]. Fuel, 2013,107(0):209-216.

[2] Lehtom ki A, Huttunen S, Rintala J A. Laboratory investigations on co-digestion of energy crops and crop residues with cow manure for methane production: Effect of crop to manure ratio[J]. Resources, Conservation and Recycling, 2007,51(3):591-609.

[3] Bidart C, Fr hling M, Schultmann F. Livestock manure and crop residue for energy generation: Macro-assessment at a national scale[J]. Renewable and Sustainable Energy Reviews, 2014,38(0):537-550.

[4] Weiland P. Anaerobic waste digestion in Germany--status and recent developments.[J]. Biodegradation, 2000,11(6):415-421.

[5] Yao Y, Luo Y, Yang Y, et al. Water free anaerobic co-digestion of vegetable processing waste with cattle slurry for methane production at high total solid content[J]. Energy, 2014,74(0):309-313.

[6] Badshah M, Lam D M, Liu J, et al. Use of an Automatic Methane Potential Test System for evaluating the biomethane potential of sugarcane bagasse after different treatments[J]. Bioresource Technology, 2012,114(0):262-269. 
[7] Comino E, Rosso M, Riggio V. Investigation of increasing organic loading rate in the co-digestion of energy crops and cow manure mix[J]. Bioresource Technology, 2010,101(9):3013-3019.

[8] Li D, Liu S, Mi L, et al. Effects of feedstock ratio and organic loading rate on the anaerobic mesophilic co-digestion of rice straw and cow manure[J]. Bioresource Technology, 2015,189(0):319-326.

[9] Kaparaju P, Felby C. Characterization of lignin during oxidative and hydrothermal pre-treatment processes of wheat straw and corn stover[J]. Bioresource Technology, 2010,101(9):3175-3181.

[10] Michalska K, Bizukoj M, Ledakowicz S A. Pretreatment of energy crops with sodium hydroxide and cellulolytic enzymes to increase biogas production[J]. Biomass and Bioenergy, 2015,80(0):213-221.

[11]Wang L, Shen F, Yuan H, et al. Anaerobic co-digestion of kitchen waste and fruit/vegetable waste: Lab-scale and pilot-scale studies[J]. Waste Management, 2014,34(12):2627-2633.

[12] Scano E A, Asquer C, Pistis A, et al. Biogas from anaerobic digestion of fruit and vegetable wastes: Experimental results on pilot-scale and preliminary performance evaluation of a full-scale power plant[J]. Energy Conversion and Management, 2014,77(0):22-30.

[13]Li J, Wei L, Duan Q, et al. Semi-continuous anaerobic co-digestion of dairy manure with three crop residues for biogas production[J]. Bioresource Technology, 2014,156(0):307-313. 